\title{
PRODUCTIVE PERFORMANCE AND SOME BLOOD PARAMETERS OF BUFFALO CALVES RAISED ON DIFFERENT FEEDING REGIMES FROM BIRTH TILL WEANING
}

\author{
Matter, Badr B., R.I. Moawd, H. El-Matarawy and T. El-Monayer \\ Animal Production Research Institute, Agricultural Research Center, Egypt
}

\section{SUMMARY}

Twenty one newly born male and female buffalo calves (12 males + 9 females) were divided depending on weight and sex into three similar groups. The effects of replacing half the requirements of buffalo milk with either soybean meal and ground corn or linseed meal and ground corn mixtures on their productive performance and some blood serum parameters were studied. Calves received experimental diets when 3 days of age up to weaning at 15 weeks of age. The first two weeks were considered as adaptation period. The experimental diets were as follows:

- Group A: $100 \%$ of allowances from buffalo milk (Control).

- Group B: $50 \%$ of allowances from buffalo milk plus 50\% of

allowances from a concentrate mixture 1 which comprised $70 \%$ ground soybean meal and 30\% ground corn.

- Group C: $50 \%$ of allowances from buffalo milk plus $50 \%$ of allowances from a concentrate mixture 2 which comprised $65 \%$ ground linseed meal and 35\% ground corn.

Calves were fed milk individually while soild feeds (starter and berseem hay) were fed ad libitum in groups from the start of the trial till weaning at 15 weeks with water available all time. Daily feed intake (for each group) and weekly body weight (for each calf) were recorded. At the $15^{\text {th }}$ week of age three digestibility trials were carried out using 3 male calves in each. Blood samples were collected at ages 15, 60 and 105 days and total protein, globulin and total lipids were determined.

\section{Results indicated the following}

- Dry matter, $C P$ and EE digestibilities of group $A$ were significantly $(P<0.05)$ higher than those for the other groups.

- Calves of group $A$ had the highest values of average daily intake as $D M, T D N$ and $C P$ while group $C$ had the lowest one.

- No significant effect of feeding regime was found on daily gain of buffalo calves.

- Calves of group B had the best feed conversion as Kg DM, TDN and $C P / k g$ gain, meanwhile, group A expressed the poorest one.

- Blood analysis showed significant increase in concentration of globulin in group $C$ and AST activity in group B when compared with the others. Meanwhile concentration of total protein, albumin, total lipids and ALT activity did not exhibit any differences. Such blood traits tend to increase with the advance of age, except for blood globulin and ALT enzyme activity where the contrary was true.

Issued by The Egyptian Society of Animal Production 
- Less feeding cost of $\mathrm{kg}$ gain was recorded for groups $B$ and $C$, while the most expensive $\mathrm{kg}$ gain cost was that for group $A$.

It be concluded that, both conventional and non conventional raising of buffalo calves are equally effective for enhancing preweaning calves growth. Therefore, up to 50\% of buffalo milk of suckling buffalo calves can be replaced by either concentrate mixture 1 (70\% ground soybean meal and 30\% ground corn) or concentrate mixture 2 (65\% ground linseed meal and 35\% ground corn) without any adverse effects on productive performance and some blood serum parameters. Reducing feeding costs due to reduction of the amount of suckling milk, may help in the relief of the problem of milk shortage in Egypt.

Keywords: Suckling buffalo calves, soybean meal, linseed meal, corn flour, performance, total protein, total lipids

\section{INTRODUCTION}

Buffalo milk production has been estimated at 3.27 million tons in Egypt, (Ministry of Agriculture, 2005). Buffalo milk is in high demand for either direct consumption or for processing. So, its price is the highest compared to that of cows and goats. The amount of whole buffalo milk required during the suckling period (15 weeks) is about $300-400 \mathrm{~kg}$. So, most buffalo holders, especially small holders sell young calves as early as possible to save milk for selling. About 45000 heads / year are slaughtered in Egypt, (Mahmoud et al., 1994a) which badly affect livestock resources.

Many attempts have been made to save this big number of slaughtered calves per year and reduce the amount of suckling milk at the same time, using milk replacers instead of expensive milk (El-Ashry, 1975; El-Ashry et al., 1988 a and b; Campos and Huber, 1983; Mahmoud et al., 1994 a and Hegazi et al., 2005); reduce the amount of required suckling milk (Ghoneim et al., 1963 and El-Bedaway et al., 1989); early weaning (Salama et al., 1989 and Raghab, 2003); using the cheaper cow milk for buffalo calves (Khattab et al., 1989 and Elready, 2006) or using soybean milk (Matter et al., 1998 and 2005 and El-Basiony et al., 2007) that can enable small holders to save the buffalo milk for selling and raising their calves to appropriate marketing weights.

The objective of this study was to investigate the effects of replacing half the requirements for buffalo milk with either soybean meal and ground corn or linseed meal and ground corn mixtures on the productive performance and some blood serum parameters of suckling buffalo calves in an attempt to reduce feeding costs of rearing.

\section{MATERIALS AND METHODS}

This study was carried out at El-Gemmeza Animal Production Research Station, Animal Production Research Institute, Agricultural Research Center, to study the effects of replacing half the requirements for buffalo milk with either soybean meal and ground corn, or linseed meal and ground corn mixtures on the productive performance and some blood serum parameters of suckling buffalo calves in an attempt to reduce feeding costs of rearing.

In this respect, twenty one newly born male and female buffalo calves were used in this study. Experimental calves were randomly divided into three similar groups of 
7 calves in each ( 4 males +3 females) according to their body weights. Calves were used directly after the colostrums feeding period at three days of age up to weaning (15 weeks old). The first 2 weeks were considered as an adaptation period. The experimental animals were subjected to the following treatments:

Group A: $100 \%$ of allowances from buffalo milk (Control).

Group B: $50 \%$ of allowances from buffalo milk plus $50 \%$ of allowances from concentrate mixture (1) (CM1).

Group C: $50 \%$ of allowances from buffalo milk plus $50 \%$ of allowances from concentrate mixture (2) (CM2).

Concentrate mixture (1) consists of $70 \%$ ground soybean meal and $30 \%$ ground corn, while CM2 consists of $65 \%$ ground linseed meal and $35 \%$ ground corn. Every 1 $\mathrm{kg}$ buffalo milk was replaced by 293 gm CM 1 (group B) or 303 gm CM2 (group C). Ground CM1 or CM2 were mixed with amount equal $50 \%$ of allowances from milk of each calf at feeding time. Chemical composition of CM1 and CM2 are shown in table (1). The calves were individually fed milk by bucket twice daily from 1 to 10 weeks of age at $8.00 \mathrm{a} . \mathrm{m}$. and at $4.00 \mathrm{p} . \mathrm{m}$. then once daily from 11 to 15 weeks of age. Daily feed allowances of calves from milk were calculated at $10 \%$ of calf body weight (Abou-Selim et al., 1991). Calves were fed milk individually while the dry feeds (starter and berseem hay) were group fed $a d$ lib starting from 2 weeks old of age. Feed residuals, if any, were weighed and the amounts consumed were recorded daily for each group. Clean water was available in free amount. Vitamin and mineral mixture blocks were provided freely. Health condition of calves has been supervise through out the entire experimental period.

Individual live body weight (LBW) was recorded weekly and then total and average daily gain (ADG) was also calculated. Blood samples were taken from all experimental calves at $15^{\text {th }}, 60^{\text {th }}$ and $105^{\text {th }}$ day of age after 3 hours of morning feeding. A sample of $15 \mathrm{ml}$ of blood per animal was withdraw from the jugular vein into clean glass tubes and left at room temperature for 45 - 60 minutes, then centrifuged at 4000 r.p.m for 15 minutes. Blood serum was separated into clean dry glass vials and stored at $-20^{\circ} \mathrm{C}$ until analysis. Representative samples of CM1, CM2, starter, berseem hay and feces were analyzed according to A. O. A. C. (1990). Whole milk samples were analyzed using milko-Scan (133 B. Foss Electronic).

Blood samples were analyzed for the following parameters: total protein (TP), albumin, globulin, aspartate amino acid transferase (AST), albumin transferase (ALT) and total lipids. Total proteins and albumine were determined according to Doumas and Biggs (1972 a \& b), and globulin was calculated by subtraction of albumin from the corresponding total protein. The AST and ALTactivities were determined as described by Reitman and Frankel (1957). Commercial kits were used for the calorimetric determination of serum total lipids.

During the experimental period, three digestibility trials were carried out using 3 calves (15 week of age) in each, to determine the digestion coefficients of the experimental rations. Fecal grape samples were taken from the rectum three times daily for five successive days as a collection period. Acid insoluble ash (AIA) was used as natural marker for nutrients digestibility determination (Van Keulen and Young, 1977).

The statistical analysis was computed carried out using analysis of variance procedure described in the SAS (1995). Differences among treatments means were tested for significance by Duncan's multiple range test (1955). 


\section{RESULTS AND DISCSSION}

\section{Chemical composition:}

Chemical composition of feed ingredients and concentrate mixtures expressed as\% on DM basis is shown in table (1). The chemical composition of buffalo milk, starter and berseem hay were within the range obtained by Matter et al. (1998 and 2005) and El - Ashry et al. (2003). Comparing CM1 to CM2 on DM basis indicated that CM1 was lower than CM2 in CF, EE and ash contents but higher in CP and NFE contents. However, CM1 contained nearly the same amount of DM as CM2. Meanwhile, the EE in CM2 was about twice that of CM1. Data showed that, the variations in the chemical composition of tested concentrate mixtures reflected their composition.

Table 1. Chemical composition (on DM basis\%) and nutritive value of whole milk, feed ingredients and concentrates mixtures used in the experiment

\begin{tabular}{|c|c|c|c|c|c|c|c|c|}
\hline \multirow[b]{2}{*}{ Items } & \multirow[b]{2}{*}{ DM\% } & \multicolumn{6}{|c|}{ Chemical composition, \% on DM basis } & \multirow[b]{2}{*}{ TDN\% } \\
\hline & & $\mathbf{O M}$ & $\mathbf{C P}$ & $\mathbf{C F}$ & $\mathbf{E E}$ & NFE & Ash & \\
\hline $\begin{array}{l}\text { Buffalo } \\
\text { milk }\end{array}$ & 16.81 & 95.12 & 23.80 & - & 39.80 & 31.52 & 4.88 & 23.50 \\
\hline $\begin{array}{l}\text { Corn } \\
\text { grains }\end{array}$ & 90.48 & 98.60 & 9.62 & 2.30 & 4.30 & 82.38 & 1.40 & 82.60 \\
\hline $\begin{array}{l}\text { Soybean } \\
\text { meal }\end{array}$ & 89.20 & 94.96 & 43.98 & 5.59 & 2.25 & 43.14 & 5.04 & 74.76 \\
\hline $\begin{array}{l}\text { Linseed } \\
\text { meal }\end{array}$ & 91.30 & 89.40 & 33.75 & 7.85 & 9.15 & 38.65 & 10.60 & 68.40 \\
\hline $\begin{array}{l}\text { Berseem } \\
\text { hay }\end{array}$ & 88.17 & 87.41 & 14.18 & 29.18 & 2.84 & 41.21 & 12.59 & 51.40 \\
\hline Starter & 88.38 & 94.52 & 17.02 & 5.62 & 3.22 & 68.66 & 5.48 & 71.90 \\
\hline CM1 & 90.45 & 97.37 & 19.67 & 3.60 & 3.95 & 70.15 & 2.63 & 80.22 \\
\hline $\mathrm{CM} 2$ & 91.10 & 95.55 & 18.19 & 4.35 & 6.20 & 66.81 & 4.45 & 77.68 \\
\hline
\end{tabular}

\section{Digestibility coefficients:}

Data in table (2) show that, DM, CP and EE digestibilities for group A were significantly $(\mathrm{P}<0.05)$ higher than for the others. These results may be due to the source of DM in the liquid diets (Akinyele and Harshbarger, 1983) or source of CP (El-Ashry et al., 1988b) or both. The reduction in CP digestibility of group C may be due to source of CP (Abou-Raya, 1967). Fonnesback et al. (1981) reported that CP digestibility was closely related to dietary $\mathrm{CP}$ level and source.

The digestibilities of EE followed the same trend as those of CP. Roy (1974) reported that the source of protein in the diet affects fat digestion, although the mechanism by which the two operate is still unclear. Verdonk et al. (2001) reported that replacing all of milk proteins in a veal calve diet led to the decrease of the apparent fat digestibility about of 7, 7, 10, 15 and 10\% for wheat gluten, soy protein isolate, soy protein concentrate, soy flour and potato protein, respectively. As shown in table (2), the CF and NFE digestibilities were not significantly different among 
groups. These results were in agreement with those obtained by El-Ashry et al. (1988b) but were lower than those obtained later by El-Ashry et al. (2003).

Table 2. Digestion coefficients (\%) of experimental rations by buffalo calves at 15 week of age

\begin{tabular}{llll}
\hline Nutrient & Group A & Group B & Group C \\
\hline DM & $72.91^{\mathrm{a}} \pm 0.13$ & $70.70^{\mathrm{b}} \pm 0.28$ & $69.60^{\mathrm{b}} \pm 1.01$ \\
$\mathrm{CP}$ & $76.90^{\mathrm{a}} \pm 0.82$ & $73.29^{\mathrm{b}} \pm 0.48$ & $71.19^{\mathrm{b}} \pm 0.84$ \\
$\mathrm{CF}$ & $49.91 \pm 0.72$ & $50.32^{ \pm} \pm 0.48$ & $51.19 \pm 0.75$ \\
$\mathrm{EE}$ & $83.70^{\mathrm{a}} \pm 0.32$ & $80.64^{\mathrm{b}} \pm 0.34$ & $81.28^{\mathrm{b}} \pm 0.90$ \\
NFE & $78.50 \pm 0.56$ & $79.50 \pm 0.46$ & $78.70 \pm 0.71$ \\
\hline a and b: Means within the same row with different superscripts differ $(\mathrm{p}<0.05)$.
\end{tabular}

From the present data, it appear that, the digestibilities of DM, CP and EE decreased after replacing $50 \%$ of buffalo milk by concentrates mixtures (CM1 \& CM2). Roy et al. (1977) stated that the apparent digestibility of DM, CP and EE decreased when non-milk protein was used in the place of milk protein, which agrees with the present study.

\section{Effect of treatments on feed intake:}

Data presented in table (3) show that, group A expressed the highest value for DM intake as kg per day (1.752), while group $C$ had the lowest value (1.637). These results are in agreement with those obtained by El-Bedawy et al. (1989) with buffalo calves fed milk at levels of 100, 75 and $50 \%$ of requirements. El-Bordeny et al. (2005) reported intake of 1.53 to $1.74 \mathrm{~kg} \mathrm{DM} /$ head/ day for buffalo calves. However, El-Ashry et al. (1988a) stated that source of protein had no effect on daily DM intake of buffalo calves fed different types of milk replacers. Fanlkner et al. (1994) also found no differences in digestible DM intake as a result of creep feed source. These results may be due to lower DM digestibility for groups $\mathrm{B}$ and $\mathrm{C}$ which led to an increase of retention time of feed in calves stomachs causing decrease of feed intake. The differences in DM intake may be attributed to the variation in a weight gain of the animals among all groups (Abdel-Raouf, 1999). El-Ashry et al. (1988b) found that, the differences in food intake may be due to the differences in body weight, DM of the substitutes and their $\mathrm{CP}$ content.

The average daily TDN and CP intake presented in table (3) followed a trend similar to that recorded for daily DM intake. The values were 1.623, 1.451 and 1.405 $\mathrm{kg}$ for TDN and 322, 303 and 290 gm for CP for groups A, B and C, respectively. These results agree with those obtained by El-Bedawy et al. (1989) and El-Bordeny et al. (2005) for buffalo calves.

\section{Effect of treatments on growth performance:}

Data concerning means of initial and weaning weights for the different groups are presented in table (4). The mean values recorded for initial and weaning weights were 42.71, 40.00 and 41.00 and $104.29,100.57$ and $99.00 \mathrm{~kg}$ for groups A, B and C, respectively. There were no significant differences among groups regarding initial or weaning weights. 
Table 3. Average daily intake* of DM, TDN and CP of buffalo calves fed different experimental rations

\begin{tabular}{llll}
\hline Items & Group A & Group B & Group C \\
\hline DM intake, kg/ day: & & & \\
From milk & 0.501 & 0.237 & 0.237 \\
From CM1 & - & 0.374 & - \\
From CM2 & - & - & 0.389 \\
From starter & 0.886 & 0.743 & 0.694 \\
From berseem hay & 0.365 & 0.328 & 0.317 \\
Total DM intake, kg/ day & 1.752 & 1.682 & 1.637 \\
TDN intake, kg/ day: & & & \\
From milk & 0.701 & 0.332 & 0.332 \\
From CM1 & - & 0.334 & - \\
From CM2 & - & - & 0.333 \\
From starter & 0.716 & 0.600 & 0.561 \\
From berseem hay & 0.206 & 0.185 & 0.179 \\
Total TDN intake, kg/ day & 1.623 & 1.451 & 1.405 \\
CP intake, gm/ day: & & & \\
From milk & 119 & 56 & 56 \\
From CM1 & - & 74 & - \\
From CM2 & - & - & 71 \\
From starter & 151 & 126 & 118 \\
From berseem hay & 52 & 47 & 45 \\
Total CP intake, gm/ day & 322 & 303 & 290 \\
\hline
\end{tabular}

* Group feeding ( 7 calves per each).

Data concerning the average daily gain of calves for the different groups (Table 4) ranged between 644 to 684 gm. Differences were not statistically significant. Calves of group A had the highest gain followed by those of groups B and C, the values being 684, 673 and $644 \mathrm{gm} /$ animal/ day for the three groups, respectively. These results agree with those obtained by El-Bedawy et al. (1989) who reported that, decreasing level of buffalo milk from $100 \%$ to $50 \%$ from allowances for calves reduced the average daily gain from 633 to $549 \mathrm{gm} /$ day. Moreover, El-Ashry et al. (1988b), showed that the daily live weight gain was reduced by inclusion of non-milk protein in the diet. These results also, agreed with those of Tjardes et al. (1998) who reported that calf performance was not significantly affected by intake level. Petit et al. (1987) and Longenbach and Heinrichs (1998) reported that any milk replacer with nutrients from vegetable sources (other than milk) decreased growth rate for calves. The results were less than the values obtained by Hilal (1985) who reported that ADG ranged between 593 to $793 \mathrm{gm} /$ day for buffalo calves. On the other hand the present results were higher than those obtained by El-Ashry et al. (1988b) who found that the ADG for buffalo calves fed half of the protein allowances as plant proteins ranged between 413 to $540 \mathrm{gm} /$ day during the experimental period ( 9 weeks). Such differences may be due to differences in the length of the experimental periods.

From the previous data, it could be noticed that, there were no significant effects on daily gain of buffalo calves due to feeding concentrates mixtures as substitution of buffalo milk up to replacement rate $50 \%$. 
Table 4. Productive performance of buffalo calves fed different experimental rations

\begin{tabular}{llll}
\hline Items & Group A & Group B & Group C \\
\hline Animal weight: & & & \\
$\quad$ Initial weight, kg & $42.71 \pm 1.21$ & $40.00 \pm 1.70$ & $41.00 \pm 1.63$ \\
Weaning weight, kg & $104.29 \pm 3.60$ & $100.57 \pm 3.46$ & $99.00 \pm 3.02$ \\
Total gain, kg & $61.58 \pm 3.58$ & $60.57 \pm 3.70$ & $58.00 \pm 2.46$ \\
Average daily gain, g & $684 \pm 40$ & $673 \pm 40$ & $644 \pm 30$ \\
Feed conversion*: & & & \\
Kg DM/ kg gain & 2.56 & 2.50 & 2.54 \\
Kg TDN/ kg gain & 2.37 & 2.16 & 2.18 \\
Kg CP/ kg gain & 0.471 & 0.450 & 0.450 \\
\hline
\end{tabular}

No significant differences among all groups.

* Group feeding ( 7 calves per each).

\section{Effect of treatments on feed conversion:}

Results obtained for feed conversion ( $\mathrm{kg} \mathrm{DM}, \mathrm{TDN}$ and $\mathrm{CP} / \mathrm{kg}$ gain) are presented in table (4). It was observed that calves of group A were less efficient when compared with groups B and C. On the other hand, calves in group B had the best efficiency as $\mathrm{kg} \mathrm{DM}, \mathrm{TDN}$ and $\mathrm{CP} / \mathrm{kg}$ gain. The results showed that calves of groups $\mathrm{B}$ and $\mathrm{C}$ converted their diets into live weight gain more efficiently than group $\mathrm{A}$. These results agree with those obtained by Nuwagaba and Kayongo-male (1983) who found that, decreasing milk intake from $10 \%$ to $5 \%$ of body weight improved feed efficiency. The DM, TDN and $\mathrm{CP}$ required to produce $1 \mathrm{~kg}$ live body gain ranged from 2.50 to $2.56 \mathrm{~kg} \mathrm{DM}, 2.16$ to $2.37 \mathrm{~kg}$ TDN and 0.450 to $0.471 \mathrm{~kg} \mathrm{CP}$. These results were lower for $\mathrm{kg} \mathrm{CP} / \mathrm{kg}$ gain and higher for $\mathrm{kg} \mathrm{DM}$ and $\mathrm{kg} \mathrm{TDN} / \mathrm{kg}$ gain than those reported by El-Bedawy et al. (1989) who reported 0.477 to $0.529 \mathrm{~kg} \mathrm{CP} / \mathrm{kg}$ gain for buffalo calves fed 100, 75 and 50\% milk from allowances. Meanwhile, they reported 2.30 to $2.56 \mathrm{~kg} \mathrm{DM} / \mathrm{kg}$ gain and 1.80 to $2.10 \mathrm{~kg}$ TDN / $\mathrm{kg}$ gain. These results were similar to those of Matter et al. (1998) who found 2.38, 2.02, 2.13 and $1.58 \mathrm{~kg}$ TDN / $\mathrm{kg}$ gain for buffalo calves fed 100, 65, 50 and zero\% buffalo milk from allowances. From the results of the experimental period of rearing buffalo calves, control group A gave the poorest feed conversion values, whereas groups B and $\mathrm{C}$ gave the best values.

\section{Effect of treatments on some blood serum parameters:}

Data in table (5) show that, neither total protein nor the albumin concentrations were significantly affected by the feeding treatments. However, replacing $50 \%$ of milk with CM2 (group C) tended to increase total serum protein compared to the other two feeding treatments (groups A and B). These results are in agreement with those reported by Mahmoud et al. (1994b) who stated that the non milk dietary protein did not significantly affect the blood total protein in buffalo calves. The average values of total protein obtained in the present study (Table 5) was affected by age. In this respect; it significantly $(\mathrm{P}<0.05)$ increased at 60 and 105 days of age compared to that at 15 days old. Mansour (1996) reported that the total protein exhibited a significant gradual increase as the animals progressed in age.

In general, the obtained values for TP (Table 5) were very close to those reported by Mahmoud et al. (1994b), Mansour (1996), Terzano et al. (1997) and ZiaUr Rahman et al. (1997). 
Table 5. Effect of different experimental rations on calves protein fraction and liver function after feeding

\begin{tabular}{|c|c|c|c|c|c|}
\hline \multirow{2}{*}{$\begin{array}{c}\text { Blood } \\
\text { components }\end{array}$} & \multirow{2}{*}{$\begin{array}{c}\text { Age of calves } \\
\text { days }\end{array}$} & \multicolumn{3}{|c|}{ Treatments } & \multirow{2}{*}{$\begin{array}{c}\text { Overall } \\
\text { mean }\end{array}$} \\
\hline & & Group A & Group B & Group C & \\
\hline $\begin{array}{l}\text { Protein } \\
\text { fraction: } \\
\text { Total } \\
\text { protein } \\
(\mathrm{g} / \mathrm{dl})\end{array}$ & $\begin{array}{c}15 \\
60 \\
105 \\
\text { overall mean }\end{array}$ & $\begin{array}{l}6.02 \pm 0.15 \\
7.66 \pm 0.16 \\
6.61 \pm 0.25 \\
6.76^{\mathrm{a}} \pm 0.19\end{array}$ & $\begin{array}{l}6.98 \pm 0.58 \\
6.52 \pm 0.16 \\
6.87 \pm 0.87 \\
6.79^{a} \pm 0.54\end{array}$ & $\begin{array}{l}6.51 \pm 0.28 \\
8.34 \pm 0.09 \\
7.75 \pm 0.63 \\
7.53^{\mathrm{a}} \pm 0.33\end{array}$ & $\begin{array}{l}6.50^{\mathrm{b}} \pm 0.34 \\
7.50^{\mathrm{a}} \pm 0.14 \\
7.08^{\mathrm{a}} \pm 0.58\end{array}$ \\
\hline $\begin{array}{l}\text { Albumin } \\
(\mathrm{g} / \mathrm{dl})\end{array}$ & $\begin{array}{c}15 \\
60 \\
105 \\
\text { overall mean }\end{array}$ & $\begin{array}{l}3.67 \pm 0.26 \\
4.31 \pm 0.41 \\
3.93 \pm 0.29 \\
3.97^{\mathrm{a}} \pm 0.32\end{array}$ & $\begin{array}{l}4.13 \pm 0.37 \\
3.60 \pm 0.22 \\
3.80 \pm 0.16 \\
3.84^{\mathrm{a}} \pm 0.25\end{array}$ & $\begin{array}{l}3.80 \pm 0.20 \\
4.05 \pm 0.38 \\
3.40 \pm 0.13 \\
3.75^{\mathrm{a}} \pm 0.24\end{array}$ & $\begin{array}{l}3.87^{\mathrm{a}} \pm 0.28 \\
3.99^{\mathrm{a}} \pm 0.34 \\
4.47^{\mathrm{a}} \pm 0.19\end{array}$ \\
\hline $\begin{array}{l}\text { Globulin } \\
(\mathrm{g} / \mathrm{dl})\end{array}$ & $\begin{array}{c}15 \\
60 \\
105 \\
\text { overall mean }\end{array}$ & $\begin{array}{l}2.35 \pm 0.16 \\
3.35 \pm 0.67 \\
2.68 \pm 0.35 \\
2.79^{\mathrm{b}} \pm 0.39\end{array}$ & $\begin{array}{l}2.85 \pm 0.17 \\
2.92 \pm 0.24 \\
3.07 \pm 0.58 \\
2.95^{\mathrm{b}} \pm 0.33\end{array}$ & $\begin{array}{l}2.71 \pm 0.08 \\
4.29 \pm 0.58 \\
4.35 \pm 1.56 \\
3.78^{a} \pm 0.74\end{array}$ & $\begin{array}{l}2.64^{\mathrm{a}} \pm 0.14 \\
3.52^{\mathrm{a}} \pm 0.50 \\
3.37^{\mathrm{a}} \pm 0.83\end{array}$ \\
\hline $\begin{array}{l}\text { Liver } \\
\text { function: } \\
\text { AST } \\
(\mathrm{U} / \mathrm{L})\end{array}$ & $\begin{array}{c}15 \\
60 \\
105 \\
\text { overall mean }\end{array}$ & $\begin{array}{l}8.50 \pm 0.68 \\
15.00 \pm 2.10 \\
13.67 \pm 3.03 \\
12.39^{\mathrm{b}} \pm 1.93\end{array}$ & $\begin{array}{l}16.00 \pm 0.58 \\
25.00 \pm 7.24 \\
14.83 \pm 1.36 \\
18.61^{a} \pm 3.06\end{array}$ & $\begin{array}{l}10.83 \pm 1.17 \\
14.17 \pm 4.70 \\
14.33 \pm 2.18 \\
13.11^{\mathrm{b}} \pm 2.68\end{array}$ & $\begin{array}{l}11.78^{\mathrm{b}} \pm 0.81 \\
18.06^{\mathrm{a}} \pm 4.68 \\
14.28^{\mathrm{ab}} \pm 2.19\end{array}$ \\
\hline $\begin{array}{l}\text { ALT } \\
(\mathrm{U} / \mathrm{L})\end{array}$ & $\begin{array}{c}15 \\
60 \\
105 \\
\text { overall mean }\end{array}$ & $\begin{array}{l}13.67 \pm 1.85 \\
12.00 \pm 1.96 \\
6.66 \pm 0.63 \\
10.77^{\mathrm{a}} \pm 1.48\end{array}$ & $\begin{array}{l}9.66 \pm 0.43 \\
10.66 \pm 1.73 \\
8.66 \pm 0.63 \\
9.66^{\mathrm{a}} \pm 0.90\end{array}$ & $\begin{array}{l}13.33 \pm 2.37 \\
11.00 \pm 1.50 \\
9.33 \pm 0.43 \\
11.22^{\mathrm{a}} \pm 1.43\end{array}$ & $\begin{array}{l}12.22^{\mathrm{a}} \pm 1.55 \\
11.22^{\mathrm{a}} \pm 1.73 \\
8.22^{\mathrm{b}} \pm 0.53\end{array}$ \\
\hline $\begin{array}{l}\text { Total } \\
\text { lipids } \\
(\mathrm{mg} / \mathrm{dl})\end{array}$ & $\begin{array}{c}15 \\
60 \\
105 \\
\text { overall mean }\end{array}$ & $\begin{array}{l}0.68 \pm 0.10 \\
0.74 \pm 0.01 \\
1.10 \pm 0.13 \\
0.84^{\mathrm{a}} \pm 0.08\end{array}$ & $\begin{array}{l}0.69 \pm 0.07 \\
0.66 \pm 0.07 \\
0.96 \pm 0.01 \\
0.77^{\mathrm{a}} \pm 0.05\end{array}$ & $\begin{array}{l}0.52 \pm 0.01 \\
0.82 \pm 0.01 \\
1.12 \pm 0.01 \\
0.82^{\mathrm{a}} \pm 0.01\end{array}$ & $\begin{array}{l}0.63^{\mathrm{b}} \pm 0.06 \\
0.74^{\mathrm{b}} \pm 0.03 \\
1.06^{\mathrm{a}} \pm 0.05\end{array}$ \\
\hline
\end{tabular}

Data in table (5) indicate that the increase in the total protein resulted from the increase of the blood globulin rather than blood albumin. It clearly appears that blood globulin in group $\mathrm{C}$ was significantly $(\mathrm{P}<0.05)$ greater than that in groups $\mathrm{A}$ and $\mathrm{B}$. An opposite but insignificant trend was found for blood albumin. These finding agree with the results of Larson and Touchberry (1959), Dubinskaya (1984) and Mahmoud et al. (1994b).

Data presented in table (5) also show that the AST enzyme activity was significantly $(\mathrm{P}<0.05)$ affected by the feeding treatments, meanwhile, the activity of ALT did not significantly differ among the experimental groups. In this respect, the greatest value of AST (18.61 U/L) and the lowest ALT value (9.66 U/L) were recorded for group B. This means that using CM1 for replacing 50\% of the buffalo milk, seems to be more effective on hepatic function than using CM2.

Data given in table (5) further indicate that ALT activity declined in the experimental groups with the advance of age. An opposite trend was noticed for AST especially in groups $\mathrm{A}$ and $\mathrm{C}$. 
Concerning the total lipid concentration in the blood of buffalo calves, it is apparent that it was not significantly affected by feeding treatments (Table 5). However, it tended to be the lowest in group B. This may be due to differences in EE content in CM replacing milk. The EE content in CM1 was about $50 \%$ of that in CM2 (Table 1).

Effect of treatments on economical efficiency:

Data presented in table (6) show the daily feeding cost (LE/ calf), feeding cost/ $\mathrm{kg}$ gain and economical efficiency of the three experimental groups of calves for the experimental period. The cheapest feeding cost / $\mathrm{kg}$ was recorded for groups B and $\mathrm{C}$, while the most expensive gain cost was that for group A. It was noticed that feeding cost/ $1 \mathrm{~kg}$ gain decreased by 39.68 and $37.82 \%$ and return/ $1 \mathrm{~kg}$ increased by 258 and $245 \%$ for groups $\mathrm{B}$ and $\mathrm{C}$, respectively compared to group A. Better economical efficiency obtained with groups $\mathrm{B}$ and $\mathrm{C}$ may be due to reducing the amount of expensive milk in groups $\mathrm{B}$ and $\mathrm{C}$ compared to group $\mathrm{A}$. These results are in agreement with Nuwagaba and Kayongo-male (1983) who found that decreasing milk intake from 10 to $5 \%$ of body weight reduced the feeding cost of suckling Friesian and Ayrshire dairy calves during the first three months of age.

Table 6. Economical efficiency of buffalo calves fed different experimental rations

\begin{tabular}{|c|c|c|c|}
\hline Items & Group A & Group B & Group C \\
\hline \multicolumn{4}{|c|}{$\begin{array}{l}\text { Average daily feed consumption as } \\
\text { fed }(\mathrm{kg}) \text { : }\end{array}$} \\
\hline Milk & 2.98 & 1.410 & 1.410 \\
\hline CM1 & - & 0.414 & - \\
\hline CM2 & - & - & 0.427 \\
\hline Starter & 1.00 & 0.841 & 0.785 \\
\hline Berseem hay & 0.414 & 0.372 & 0.360 \\
\hline Average daily gain, $\mathrm{kg}$ & 0.684 & 0.673 & 0.644 \\
\hline Daily feeding cost, LE/ head & 10.67 & 6.33 & 6.25 \\
\hline Feeding cost, LE/ kg gain & 15.60 & 9.41 & 9.70 \\
\hline Relative cost of $\mathrm{kg}$ gain* & 100 & 60.32 & 62.18 \\
\hline Price of weight gain, LE/ kg & 12.31 & 12.11 & 11.59 \\
\hline Return, LE & 1.64 & 5.78 & 5.34 \\
\hline Return, LE/ kg gain & 2.40 & 8.59 & 8.29 \\
\hline Improving in return/ $\mathrm{kg}$ gain & - & $258 \%$ & $245 \%$ \\
\hline Economic efficiency** & 1.15 & 1.91 & 1.85 \\
\hline \multicolumn{4}{|c|}{$\begin{array}{l}\text { * Assuming that feeding cost of kg gain of the control (A) equal } 100 \text {. } \\
\text { ** Economical efficiency = Price of the weight gain/ daily feeding cost. } \\
\text { The price of feedstuffs and body gain: }\end{array}$} \\
\hline \multicolumn{4}{|c|}{$\mathrm{CM} 1=1510 \mathrm{LE} /$ ton $\quad \mathrm{CM} 2=1500 \mathrm{LE} /$ ton } \\
\hline
\end{tabular}

It can be concluded that, both conventional and non conventional raising of buffalo calves are equally effective for enhancing preweaning calves growth. Therefore up to $50 \%$ of buffalo milk of suckling buffalo calves can be replaced by either concentrate mixture 1 (70\% ground soybean meal and 30\% ground corn) or concentrate mixture 2 (65\% ground linseed meal and 35\% ground corn) without any 
adverse effects on productive performance, and some blood serum parameters. Reducing feeding costs due to reduction of the amount of suckling milk, may help in the relief of the problem of milk shortage in Egypt.

\section{REFERENCES}

Abdel-Raouf, E.M., 1999. Performance of Friesian calves fed different dietary levels of ascorbic acid during suckling period. Egypt. j. Nutr. and Feeds, 2 (Special Issue). 437-444.

Abou-Raya, A.K., 1967. Animal and Poultry Nutrition. $1^{\text {st }}$. Edit. Pub. Dar-El-Maarif, Cairo (Arabic Text Book).

Abou-Selim, I.A., Hanna El-koussy and A.M. Mahmoud, 1991. Feeding Suckling buffalo calves on different amounts of milk on their performance till weaning. Annals Agric. Sci., Ain Shams Univ., Cairo, 36 (1):129 - 135.

Akinyele, I.O. and K.E. Harshbarger, 1983. Performance of young calves fed soybean protein replacers. J. Dairy Sc., 66: 825-832.

A.P.R.I., 1997. Animal Production Research Institute. Animal Nutrition (Scientifically and Practically) $1^{\text {st }}$ Ed. Animal Production Research Institute, Agriculture Research Center, Ministry of Agriculture, Dokki, Giza, Egypt (In Arabic ).

A.O.A.C., 1990. Association Official Analytical Chemists. Official Methods of Analysis. $13^{\text {th }}$.Ed. Washington, D.C.U.S.A.

Campos, O.F. and J.T. Huber, 1983. Performance and digestion by calves from limestone added to milk replacers containing soy protein concentrate. J. Dariy Sci., 66: $2365-2372$.

Doumas, B. T. and H. G. Biggs, 1972a. The colorimetric determination of total protein in serum or plasma. Standered Methods of Clinical Chemistry. Vol 7. Academic press. New York.

Doumas, B. T. and H. G. Biggs, 1972b. The colorimetric determination of albumin in serum or plasma. Standered Methods of Clinical Chemistry. Vol 7. Academic press. New York.

Dubinskaya V.P., 1984. Effect of whole milk replacer containing Meprin on blood biochemistry and nitrogen balance in young cattle. Moscow, USSR (1984) 14-19. (C.F. Nutr. Abst. and Rev. $56: 810$ ).

Duncan, D.B., 1955. Multiple Range and Multiple F. test. Biometrics, 11:10.

El-Ashry, M. A.; A.M. El-Serafy and O. Shehata, 1975. A note on the performance of buffalo calves fed different milk replacers. J.Anim. Sci., $45: 234$.

El-Ashry, M.A.; A.M. El-Serafy; A.A. Zaki and H. Soliman, 1988a. Plant protein in milk replacers for rearing buffalo calves. 1- Effect of replacing half of the milk proteins by plant proteins on the pre-weaning performance of buffalo calves. Beitrage trop. Landwirtsch. Veterinarmed. 26 (2): $189-195$.

EL-Ashry, M.A.; A.M. El-Serafy and A.A. Zaki, 1988b. Plant Protein in milk replcers for rearing buffalo calves.2-Effect of replacing $75 \%$ of the milk proteins by plant proteins on the pre-weaning performance of buffalo calves. Beitrage trop. Landwirtsch. Veterinarmed. 26 (1): $55-65$.

EL-Ashry, M.A.; Salwa, M. Hamdy; A.M.Mansour; M.M. Khorshed and E.M.ElKotamy, 2003. Studies on performance of buffalo calves fed on acidified milk. Egypt. J. Nutri. and Feeds, 6 (1) : 1-11. 
El-Basiony, A.Z.; S.M. Abdelmawla; M. Abdelfttah and Sh. G. Osman, 2007. Partial replacement of buffaloe's milk by soymilk effects on digestibility and performance of new-born calves. Egypt. J. Nutr. and Feeds, 10(2) (Special Issue): $425-436$.

El-Bedawy, T.M., M.A.M. Salama and L.H. Bedeir, 1989. Effect of restricted milk intake on productive performance of buffalo calves up to six months of age. $3^{\text {rd }}$ Egypt. - Brit. Conf. on Anim., Fish and Poul. Prod., Alexandria, Egypt, 2: 521533.

El-Bordeny, N.E.; M.A. El-Ashry; H.M. khattab and H.M. El-Sayed, 2005. Effect of some medicinal herbs on buffalo calves performance from first week old till weaning. Egyptian J. Nutrition and Feeds, 8 (1) (Special Issue): 155-166.

Elready, K. F. A., 2006. Rearing buffalo calves under different feeding system. Ph.D. Thesis, Fac. of Agric., Kafr El-Sheikh,Tanta Univ.

Fanlkner, D.B., D.F. Hummel, D.D. Buskirk; L.L. Berger; D.F. Parrett and G.F. Cmarek, 1994. Performance and nutrient metabolism by nursing calves supplemented with limited or unlimited corn or soyhulls. J. Anim. Sci., 72 (2): 470-477.

Fonnesback, P.V., J.L. Christiansen and L.E. Harris, 1981. Factors affecting digestibility of nutrients by sheep. J. Anim. Sci., 52:363-376.

Ghoneim, A.; A. K. Abou-Raya and E. R. M. Abou - Hussein, 1963. Feeding suckling calves in Egypt on a certain level and reduced allowances of milk. Proceed. Soce. Animal Pro. Conf., Cairo, 2: 275.

Hegazi, S. M; A. A. Bakr; B. I. Agag and M. A. Mosa, 2005. Influence of fat increment in milk replacer on performance of buffalo calves. Egypt. J. Nutr. and Feeds, 8 (1) (special issue): $253-269$.

Hilal, F.I.S., 1985. The effect of energy density and source in milk replacers on the productive performance of buffalo calves. Ph.D. Thesis, Fac. of Agric. Ain Shams Univ.

Khattab, H.M., E.E. Ragheb and A.Z.El-Basiony, 1989. Milk replacer versus natural milk for raising buffalo calves. $3^{\text {rd }}$ Egyp. -Brit. Conf. on Anim., Fish and Poul. Prod., Alexandria, Egypt, 2: 513 - 519.

Larson, B.L. and R.W. Touchberry, 1959. Blood serum protein level as a function of age. J.Anim. Sci., 18:983.

Longenbach, J.I. and A.J. Heinrichs, 1998. A review of the importance and physiological role of curd formation in the abomasums of young calves. Anim. Feed Sci. and Tech., 73:85-97.

Mahmoud, S.A.S.; F.Z. Swedan; M.A. El-Ashry; M.M. Mesbah and K.D. Gunther, 1994a. Nutritional study of different rearing systems on buffalo calf performance. 1- Growth rate and digestitbility. Alexandria J. of Agric. Res., 39(3): 93-108.

Mahmoud, S.A.S.; F.Z. Swedan; M.A. El-Ashry; M.M. Mesbah and K.D. Gunther, 1994b. Nutritional study of different rearing systems on buffalo calf performance. 2- Ruman and blood parameters. Alexandria J. of Agric. Res., 39(3): 109-121.

Mansour, A.M., 1996. The effect of some growth promoters on productive efficiency of buffalo calves. Ph.D. Thesis, Fac. Agric. Ain Shams Univ., Cairo.

Matter, Badr, B.; H.M. Radwan; H.M. Fayek and N.A. Ibrahim, 1998. Soymilk as buffalo milk substitute in feeding new born buffalo calves. Egypt. J. Appl. Sci., $13(7)$. 
Matter, Badr, B.; H.M. Radwan and N. A. Ibrahim, 2005. Soymilk as buffalo milk substitute in feeding new born buffalo calves. 1- The effect of replacement of whole buffalo milk by soybean milk on suckling buffalo calves performance. Egypt . J. Agric. Res., 83 (1) : 389- 403.

Ministry of Agriculture, 2005. A study for main statistical parameters for livestock, poultry, fish and bees resources. (in Arabic), Volume 10.

Nuwagaba, H.M. and H. Kayongo-male, 1983. Comparison of performance between bucket-fed and nipple - fed dairy calves on different levels of milk intake. Trop. Anim. Prod., 8:206.

Petit, H.V.; M. Ivan and G. J. Brisson, 1987. Duodenal flow of digesta in preruminant calves fed clotting or nonclotting milk replacer. J. Dairy Sci., 70 : 2570-2576.

Ragheb, E.E., 2003. Effect of lacto-sacc and acid pak additives on productive performance of Friesian calves under early weaning system. Egypt. j. Nutr. and Feeds, 6 (2): 127-137.

Reitman, S. and S. Frankel, 1957. A colorimetric method for determination of serum glutamic oxaloacitic and glutamic pyruvic transaminase. Amer. J. Clin. Path., 28, $56-63$

Roy, J.H.B., 1974 . Problems in the nutrition of the preruminant calf. Proc. Nutr. Soc. 33: 79.

Roy, J. H.B.; I.J.F. Stobo; S.M. Shotten ; P. Ganderton and C.M. Gillies, 1977. The nutritive value of non milk proteins for the preruminant calf. The effect of replacement of milk protein by soybean flour or fish protein. Brit. J. Nutrit. 38 : 167 .

Salama, M.A.M.;T.M. El-Bedawy and L.H. Bedeir, 1989. Effect of early weaning on productive performance of buffalo calves up six months of age. $3^{\text {rd }}$ Egyp. - Brit. Conf. on Anim., Fish and Poul. Prod., Alexandria, Egypt, 2: 535-551.

SAS (1995). SAS Users Guide, Statistical Analysis System Institute Inc., N.C.U.S.A.

Terzeno, G.M.; A. Zasso; R.I. Barile; C. Pacelli; N. Montermurro; and A. Borghese, 1997. Effect of feeding system and puberty on blood metabolites trend in buffalo heifers. Proc. $5^{\text {th }}$ World Buffalo Congress, 13-16 Oct., Caserta, Italy, 25 pp.

Tjardes, K. E.; D.B. Fanlkner; D.D. Buskirk; D.F. Parrett; L.L. Berger; N.R. Merchen and F.A. Ireland, 1998. The influence of processed corn and supplemental fat on digestion of limit-fed diets and performance of beef cows. J. Anim. Sci., 76 (1): 8-17.

Van Keulen, J. and B.A. Young, 1977. Evaluation of acid - insoluble ash as a natural marker in ruminants digestibility studies. J. Anim. Sci., 44: 282-287.

Verdonk, J.M.; A.J. Gerrits; W.J.J. Beynen and A.C. June, 2001. Replacement of milk protein by vegetable protein in milk replacer diet for calves: digestion in relation to intestinal health. Proceeding of the Symposium "Nutrition and gut health" organized by Dutch boards of commodities and feedstuffs. Nijkerk, the Netherlands.

Zia-ur Rahman, U.; U. Hag; I. Javed; M. Hassan; Z. H. Nagui; M.M. Asif and M. ajjaivi, 1997. Hormonal and hematological profiles in buffalo after transport, handling and after slaughter stress. Proc. $5^{\text {th }}$ World Buffalo Congress, 13-16 Oct., Caserta, Italy, $30 \mathrm{pp}$. 


\section{الأداء الإنتاجي ويعض قياسات الام في العجول الجاموسي المنشأة على نظم غذائية مختلفة من الميلاد حتى الفطام}

\section{بلر بسطويسي مطر ، رأفت إبراهيم معوض، حدي المطراوي، طارق المنير \\ معهُ بحوث الإنتاج الحيواني ، مركز البحوث الزراعية ، جمهورية مصر العربية}

$$
\begin{aligned}
& \text { استخدم في هذا البحث بr عجل جاموسي حديث الولادة (r ا ذكر + 9 إناث) قسمت إلى ثلاثة }
\end{aligned}
$$

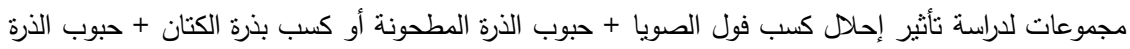

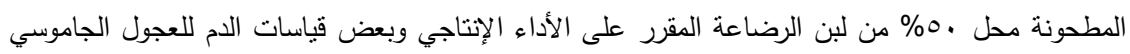

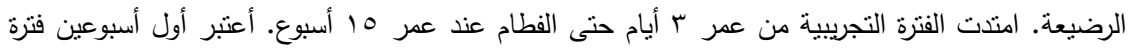

$$
\begin{aligned}
& \text { أقلمة. طوال الفترة التجريبية غذيت العجول على العلائق التجرييية التالية: }
\end{aligned}
$$

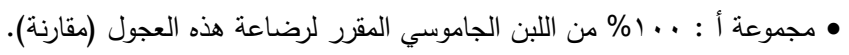

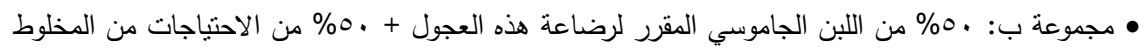

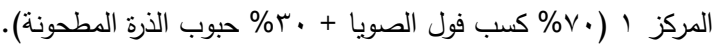

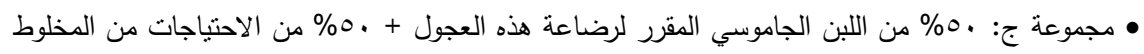

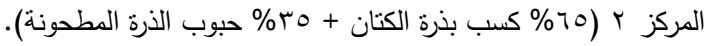

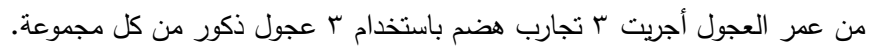

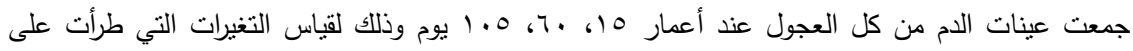

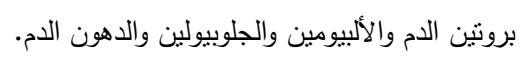

$$
\begin{aligned}
& \text { فيما يلي أهم نتائج هذه الدراسة: }
\end{aligned}
$$

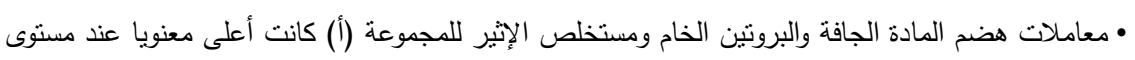

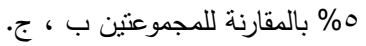

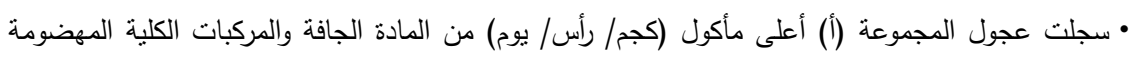

$$
\begin{aligned}
& \text { والبروتين الخام تليها عجول الدجموعة (ب) ثم المجموعة (ج). }
\end{aligned}
$$

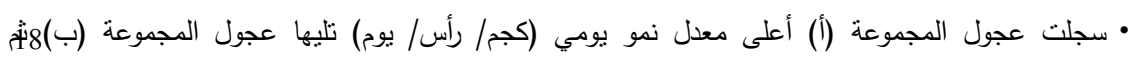

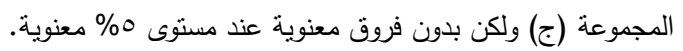

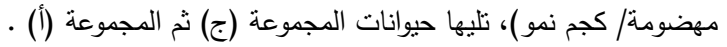


كما لوحظ زيادة معنوية في مكونات الدم السابقة مع زيادة العمر فيما عدا تركيز الجلوبيولين ونشاط ALT

$$
\text { • ALT }
$$

• أظهر التقييم الاقتصادي أن أقل تكلفة تغذية لكل كجم نمو كانت لحيوانات المجموعة (ب) تليها المجموعة

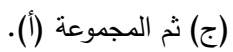

• تشير نتائج هذه الدراسة إلى أن التنشئة التقليدية وغير التقليدية للعجول الجاموسي الرضيعة لها نفس التأثير

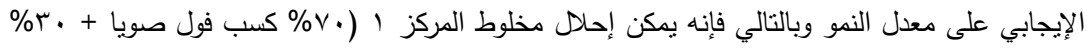

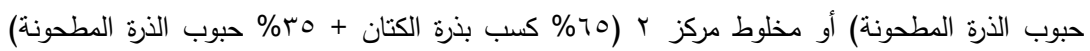
محل •0\% من كمية اللبن المقررة للعجول الجاموسي الرضيعة دون حدوث أضرار على الأداء الإنتاجي لهذه العجول وكذلك على بعض قياسات الدم مع خفض تكلفة التغذية والمساعدة في حل مشكلة نقص اللبن 